\title{
Power and Truth in Atwood's The Blind Assassin
}

\author{
Roshanak Fazli \\ Payam Noor University of Amol, Mazandaran, Iran \\ Ehsan Hafezikermani \\ Payam Noor University of Amol, Mazandaran,Iran
}

\section{Introduction}

Margaret Atwood's The Blind Assassin fits the framework of a story-within-storywithin-story. The first narrator is a memoir of Iris Chase Griffen. In this memoir, Iris divulges her family history, including the story of her grandparents and parents. The second narrative is a novel called "Blind Assassin." It is theoretically written by Laura Chase, Iris's sister. It portrays a love affair between a woman and a man. And the third narrative is some pieces of newspaper.

Although the novel is made of three different genres, the emphasis of relationships between men and women is noticeable. Indeed power relations are rooted deep in the social and private network of the characters' lives. To live in this network is to live in such a way which 'actions upon other actions' is probable and constant. Individuals circulate in the network of power. They are always in the position of experiencing and exercising power. As explained in Foucault's concept of power, individuals do not dominate others, nor does or one group or class. It is a kind of mutual relationship.

There are assorted groups of relationships in the Blind Assassin which I would like to take under observation. The relationships are: Iris and Richard; Richard and Laura; Iris, Laura and their father; and Iris and Alex. Everyone in these groups demonstrates power and their subjectivity through sex; mimicry and writing are claimed.

In the following pages, I shall purpose to explicate women's emergence from the shadow of objection as an equal force in a supposedly patriarchal society. In other words, by demonstrating women's unnoticed power alongside men's acknowledged power, I intend to show the battleground of power and discard the domination of one group over another. 


\section{Father, Mother and Daughters' Relationships}

Discussing this novel, many critics like Karen F. Stein and Elaine Showalter accentuate the issue of gender. They claim Atwood's priority is to criticize the restraint of women in a patriarchal society. Iris, an eighty-two-year-old woman, narrates the story in the form of a family history, including the story of her grandparents and parents.

On the one hand, women are objectified in this phallocentric society. Women are sacrificed sexually under a patriarchal system. Correspondingly, there are some symbols, metaphors and concepts taken for granted as imposed roles and phenomenon under the patriarchal system.

Liliana, Iris and Laura's mother, dies from a miscarriage, so Iris has to be a good older sister to Laura. There are two explanations; Liliana was a pious woman, the patriarchal concept and demand of a good angelic woman. Thus she dictates the authorized concept of womanhood to Iris. However, this can be seen as a sisterhood bond advised by a mother. Society wants women to be angelic and pious; but it does not demand the same from men. Norval, Liliana's husband, should run his factory more prudently. Returning from war, wounded and limp, he is supposed to be a hero. Out of detailed descriptions in the novel, he is not psychologically healthy and is tolerated by his wife. Norval seems like a broken vase to be mended, but on behalf of men; this patriarchal society even mistreats a man. In fact, being a heroic warrior is what the society requires. He finds himself overwhelmed by the responsibility of a collapsing factory. On the other hand, his wife dies and he is left with two daughters. As Bouson says about the relationship between the father and two daughters, "[...]she turns thirteen and is suddenly subjected to her father's surveillance." (256) It can be comprehended through Iris, the main narrator, that the sisters were learning about the rules of women's roles under their father's observation. But their father was not the only source. Even Reenie, their cook, taught them about sexual misbehavior. As stated in the novel, "Reenie didn't waste any sleep on my account, but Laura in her opinion was too confiding, too cozy with strangers. The white slavers were always on the prowl, and Laura was their target." (178) Therefore, it cannot be claimed that they were under pressure just by their father. As Foucault says in his Truth and Power, "It is customary to say that bourgeois society repressed infantile sexuality to the point where it refused even to speak of it or acknowledge its existence." (120) Their father is just another victim of the patriarchal society and tries to survive.

In this society, there is no domination of men over women. They are just fighting, struggling and trying to survive. Moreover, power is subjected in different forms 
and ways. For their father, compatibility with the majority was a method to repossess his power as a human being in this network of power. Power is not an institution nor a structure. It is just a name attributed to a situation in a special society. Individuals are always exercising and being subjected to power. Taking Norval as an example, I believe that he simultaneously practices power and it subject to it.

\section{Richard and Iris}

To protect the collapsing factory, Norval marries his older daughter, Iris, to a rich man called Richard. That can be taken as an example of exercising power over his daughter. However, Iris never forbid the idea even if she was asked to have the final say herself. Likewise, in the novel, their father says: "But naturally... whatever decision you make will be your concern...I couldn't want you doing anything you are dead against." (232)

Norval expected he could regain his family's lost power by clinging to powerful people. According to the main narrator, Iris, his dream did not come true. Indeed, the system of a society formed based on power forces makes a person like Norval act bizarrely. As Foucault stated in an interview, "Man is a thinking being. The way he thinks is related to society, politics, economics, and history and is also related to very general and universal categories and formal structures." Thus Norval, alongside other people in this novel, is the society's fruit and is involved in an ongoing, nonstop game.

On the other hand, in Truth and Power, Foucault believes structures are shaped by the guidelines of society. People overlook some events to create the general tide of history. They deliberately do not pay attention to the inapt events that do not fit into "those beautiful structures that are so orderly, intelligible and transparent to analysis" (114) Likewise, in Blind Assassin, Iris is like a historian narrating the history of a family tragedy, but it is felt throughout the story that something is missing; that is, she is the only narrator and except for some minor hints, there is no proof for her points. She, like a historian, evaporates elaborate events and just relates clear events acceptable to sympathizing readers. Therefore most of the events relating to the female abjection cannot be taken for granted.

Of the chain of events rendered by Iris, one is her relationship with Richard, her husband. Iris tries to prove that she was sexually abused by Richard. She acted as a dutiful daughter to be given by her father to Richard. As Bouson (257) put it, 
"Atwood's description of the circumstances surrounding Richard's proposal to Iris is a scathing critique of patriarchal marriage and historical treatment of women."

But first of all, Richard is not responsible for her blind acceptance to marry him. Iris stigmatizes Richard for hypocrisy, but forgets her main reason of marriage: to save Chase factory, and to keep Laura in safe hands. On the night of the marriage, even Laura had talked to her in hopes of persuading Iris to break it off: (242) "'It's not right,' she said. 'It's not right at all. You could break it off, it's not too late. You could run away tonight and leave a note. I'd come with you."'

Not only does Iris take her seriously, but tries to convince Laura it is the most sensible thing to do. Nevertheless, she shows a hidden fear that marriage is a kind of female bondage when she depicts her feeling on the honeymoon voyage:

“... I sat on the edge of the bed, staring at my open steamer trunk. It was a very fashionable one, a pale yellow on the outside but dark blue on the inside, steel- bound, the nail- heads twinkling like hard metallic stars. But it seemed to me full of darkness- of emptiness, empty space."(243)

It seems Iris' marriage is basically resentful. She seems to have some formed conjectures about marriage. It may be due to the outcome of her parents' failed marriage or unexposed nagging and feelings of the women around her, especially Reenie. These preformed fears and feelings are the products of society. Society wants a girl to feel unwisely obedient and thoughtlessly hate a human just because he is going to be her husband, not a secret lover!

Moreover, all through the novel, Iris talks about Richard's dominance. In fact, he is not a caring guardian but a suppressor. But Iris herself never acted reasonably and neither did anything vigorously. She was just a passive bride, wife and a sister. Never caring about her relationship with Richard, Iris did not even pay attention to the events going on around her in her house. Her only courageous action was fooling around with Alex, which is hard to prove, for nobody witnessed anything.

\section{Alex and Iris}

Iris was not fascinated with intercourse with Richard. She supposed it something to be endured, not adored. When they returned home after the honeymoon, Iris went to the bedroom and these were her thoughts: "This, then, was where I was to grin and bear it- the bed I hadn't made, but now must lie in it. And this is the ceiling I would be I would be staring up at from now on, through the muslin fog, while earthly matters went on below my throat."(316) 
For her, it seemed to be a hurting objectification in a masculine system in which she was a sexual object. But here the question arises of why she did not claim her feminine identity in relation to Alex, though Alex did not show up as a promising lover. Alex hurts her outspokenly and scorns romantic love. As he says in one scene in the cafe, "you will get thin, and then your lovely tits and ass will waste away to nothing. You will be no good to anybody then."

If this sexual assault is not similar to Richard's, it is not less harmful. In fact, it is not just Richard who seems to be a molester, Alex is also. The fact is that both Richard and Alex are the products of this kind of society which makes them struggle and reclaim their identity through sex. But sex is not the only means of oppression in men's hands. It is also in the command of women. Iris takes revenge on Richard by having an affair with Alex and later publishes its detailed story under Laura's name again to retaliate against Richard. According to Bertens,

"In her 1974 essay ; The Laugh of Medusa', Cixous suggest that laughter, sex (if not policed by patriarchal heterosexuality), and writing may have liberating effects. Aware that writing usually serves the consolidation of patriarchal power, Cixous proposes what she calls e`criture fe`minine, that is a feminine or female writing that will escape the restrictions imposed by the phallocentric system.”(166)

So domination is not a part of this image; rather, the dominating image in which all men and women participate renders the battleground.

\section{Laura and Richard}

Society creates truth. There is a wrong/false truth accepted in society which makes people believe in certain ways. As Foucault believes, truth is a system of organized processes for different statements. And truth is accompanied by the system of power. Truth and power go side by side. It is a false truth in Blind Assassin that a woman should be pious and angelic. It is also a false truth that Laura was raped and tortured by Richard against her wishes. Laura suppressed herself as a child to restore her dead mother and some years later she did have a sexual relationship with Richard to save Alex. Therefore it can be implied that Laura was not a total victim; she might be a part of this story of sex and rape. The false truth is that society might be against men in this case. The two sisters, especially Iris, took advantage of this idea. She knew people are always after rumors and false truth, which are exciting. 
Laura and iris had used this kind of hoax before, when Mr. Erskine was their tutor. As Bouson says (256),"'hired by Norval and acting as his agent, Mr. Erskine is an embodiment of the repressive forces of masculinist culture. In a series of scenes deliberately staged by the narrative to make apolitical points, Mr. Erskine subjects the sisters to various forms of emotional and physical abuse." I take it for granted as mentioned in the novel: (167) "...from Ovid's Metamorphoses, the parts where unpleasant things were done by the gods to various young women. The rape of Europa by a large white bull, of Leda by Swan, of Dnae by a shower of gold- these would at least hold our attention, he said, with his ironic smile."

But these are Iris's words. There are not any other fallible narrators. Laura and iris did not like to have a tutor at all, even the female teacher whom they bothered a great deal. At the beginning of the chapter concerning Miss Violence, Iris says, (156)

"Instead of school, Laura and I were provided with a succession of tutors, men and women both. We didn't think they were necessary, did our best to discourage them. We would fix them with our light- blue stores, or pretend to be deaf or stupid; we'd never look them in the eye, only in the forehead. It often took longer than you'd think to get rid of them: as a rule they'd put up with quite a lot from us, because they were browbeaten by life and needed the pay."

On the other hand, the sisters are not just mere victims mistreated and tortured. They used the given power in the sullied society. They disgraced Mr. Erskine. Unproved and undetected, the whole idea about him rendered by Laura was accepted and approved by Reenie. She helped them convince their father that Mr. Erskine was a sexual pervert. If Mr. Erskine used his power as a man to abuse the girls, then they used their power to stigmatize him. When Reenie was informed by Laura and Iris about him,

"four days later she marched in to father's office at the button factory with a handful of contraband photographs. [...] she said she'd found them under Mr. Erskine's bed when she'd been sweeping out his room, and was this the sort of man who ought to be trusted with Captain Chase's young daughters?"(169)

Thus the idea of battle between forces is more obvious than the domination of a group over others. Both men and women act similarly to fight and win. Even men are against each other, do not trust each other, hate and fear. Father believes gossip about Mr. Erskine more than Mr. Erskine's words and claims. So both men and women are entangled in the network made by society. 


\section{Conclusion}

Summing up, there is an endless war of all against all in the civilized societies we are living in. The supposed power will be transmitted from one hand to another, but the big social war of survival is undying and is only changed in the form in which it emerges, not in the original concept.

Thus the characters in Blind Assassin do not dominate over each other for good. They act and react to survive because they are socially informed about which power they need to survive. They learn to seek various methods. If men use sex in bed, women use it in another way to gain power and domination. If society gives some rights to men for surveillance, women use writing and its power. So power is distributed in a network and the whole social body, including both men and women, fights over it.

\section{References and Notes}

Atwood, Margaret. The Blind Assassin. New York: Anchor, 2001

Berten, Hans, Literary theory: the Basics, London: Routledge, 2001

Bouson, J. Brooks. "A Commemoration of wounds endured and resented: Margaret Atwood's the Blind assassin. Assassin as Feminist Memoir." Critique: Studies in Contemporary Fiction 44.3 (2003): 251-69

Cixous, Helen. "The Laugh of the Medusa." 1976. Trans. Keith Cohen and Paula Cohen. New French Feminists: an Anthology. Ed. and intro. Elaine Marks and Isabelle de Courtivron. New York: Harvester, 1980. 245-64

Gordon, Colin. Foucault, M. (1980). Power/Knowledge: Selected Interviews \& Other Writings 1972-1977. Pantheon Books, New York (Alessandro Fontana, Pasquale Pasquino "Truth and Power, Interviewers" 109-131)

Gutting, Gray. Foucault: A very short Introduction. Oxford University Press. 2005

Martin, L.H. et al. "Truth, Power, self: an Interview with Michel Foucault. October 25th 1982.," Technologies of the self: A seminar with Michel Foucault. London: Tavistock. (1988). Pp.9-15

Showalter, Elaine The New Feminist Criticism, New York: Pantheon. 1985

Stein, Karen F. "A left handed story: the Blind Assassin." Margaret Atwood's Textual Assassinations: Recent Poetry and Fiction. Ed. Sharon Rose Wilson. Columbus: Ohio State, (2003). 135-53

Yildirim Koyuncu, Nevin. "Revising script of femininity in Margaret Atwood's the Blind Assassin." Interactions 16:2 (Fall 2007): 73-86. 


\title{
Summary
}

\section{Power and Truth in Atwood's The Blind Assassin}

\author{
Roshanak Fazli \\ Payam Noor University of Amol, Mazandaran, Iran \\ Ehsan Hafezikermani \\ Payam Noor University of Amol, Mazandaran,Iran
}

\begin{abstract}
The present paper explicates the power relations in the social and private networks of the characters' lives in Margaret Atwood's The Blind Assassin. Several groups of relationships are observed to demonstrate noticed and neglected power forces among men and women in the story. Thus the battleground is depicted and the domination of men over women will be rejected. Using Foucault's ideas about power and truth, I try to display the conflict of all against all in the novel and likewise in the civilized society we live in.
\end{abstract}

Key words: Mimicry, Phallocentric, Patriarchal, Fallible narrator. 